
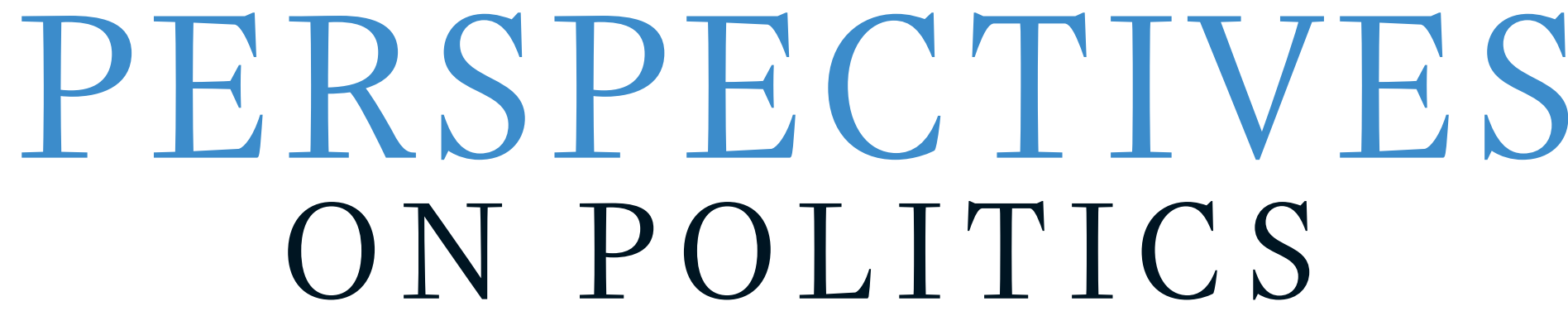

A Political Science Public Sphere | June 2014, Volume 12, Number 2

\title{
The Ballot and the
} Street: An Electoral Theory of Social Protest in Autocracies

Guillermo Trejo
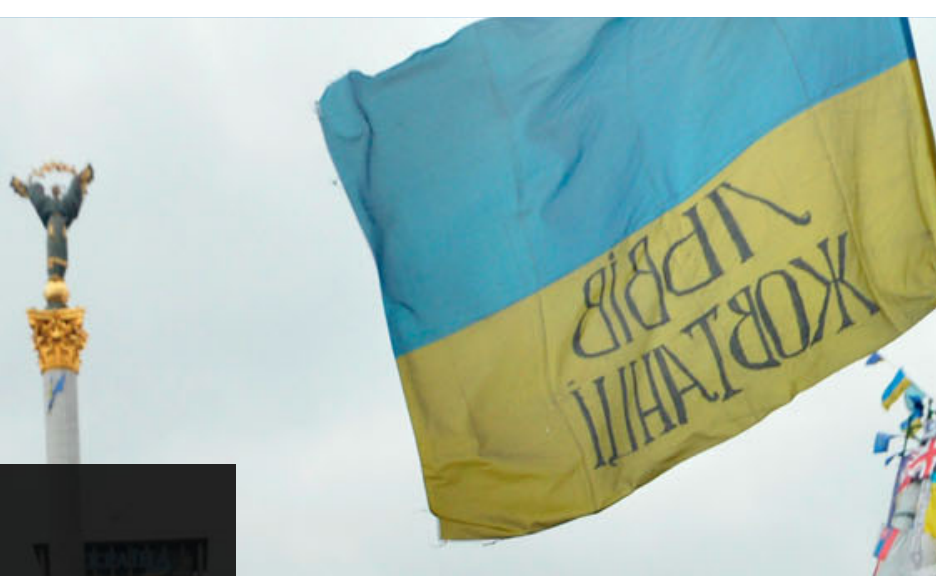


\section{KANSAS}
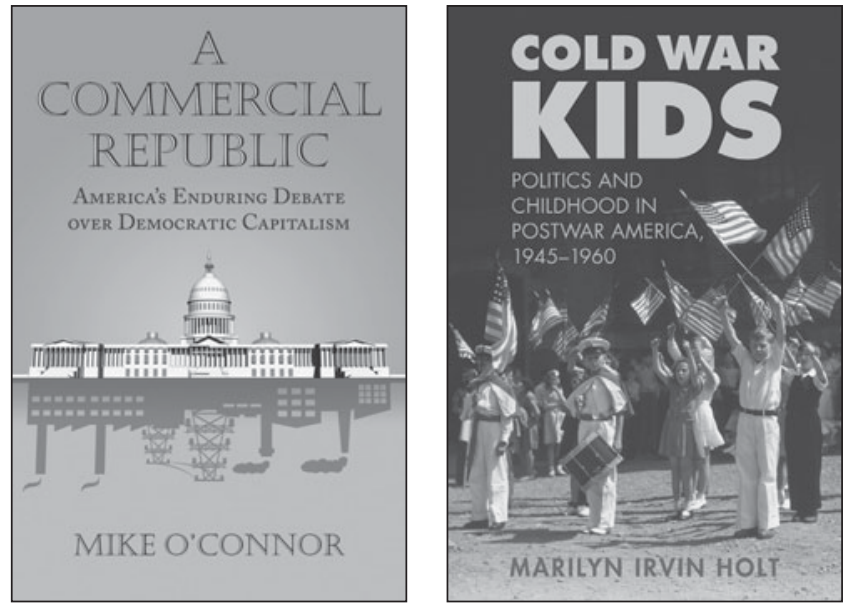

\section{A Commercial Republic}

\section{America's Enduring Debate over Democratic Capitalism}

Mike O'Connor

"Mike O'Connor takes readers on a meticulously researched, elegantly written, and endlessly fascinating tour of America's great economic brawls. Along the way he explodes one of the nation's most stubborn myths. This formidable book has much to teach scholars, citizens, and anyone who enjoys a well-told history."-James A. Morone, author of Hellfire Nation

American Political Thought

320 pages, 10 photographs, Cloth $\$ 34.95$

\section{Landmark Law Cases and} American Society

Peter Charles Hoffer and N.E.H. Hull, series editors

\section{Judging the Boy Scouts of America}

\section{Gay Rights, Freedom of}

Association, and the Dale Case

Richard J. Ellis

"With the Boy Scouts of America v. James Dale case, the Constitution becomes a Procrustean bed-in fact, a whole room of them. Ellis's account is riveting."-Karen Orren, Professor of Political Science at UCLA

"It's the most comprehensive and accurate narrative of early legal actions against the Scouts I've ever seen; I learned things I didn't know about my own lawsuit."-Tim Curran, journalist and plaintiff, Curran v. Mt. Diablo Council 296 pages, Cloth $\$ 34.95$, Paper \$17.95, Ebook \$17.95
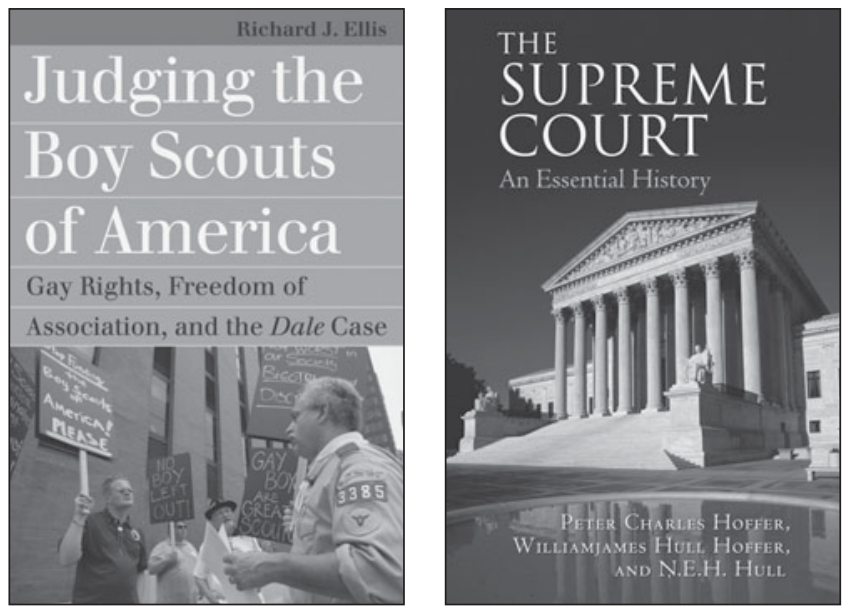

\section{Cold War Kids}

\section{Politics and Childhood in Postwar America,} 1945-1960

Marilyn Irvin Holt

"A brisk and nuanced foray into the unexplored decade-anda-half before the troubled and dramatic 1960s. From health to entertainment, from education to housing, and from crime to welfare-with insights into the effects of race, class, and gender sprinkled throughout-Holt covers all of the pertinent issues tentatively addressed by postwar politicians and policy-makers as they took the first steps toward reimagining the government's role in the lives of American families and children."- James Marten, President of the Society for the History of Children and Youth 224 pages, 24 photographs, Cloth $\$ 34.95$, Ebook $\$ 34.95$

\section{New in Paperback}

NEW IN PAPERBACK

\section{The Supreme Court}

\section{An Essential History}

Peter Charles Hoffer, Williamjames Hull Hoffer, and N.E.H. Hull

"[It] may well be the best single volume history of the Court ... on the whole, balanced and brings together an extraordinary amount of material. It even uncovers some gems along the way.... The authors [are] a remarkable family of scholars."-Political Science Quarterly 504 pages, 25 photographs, Paper $\$ 29.95$ 


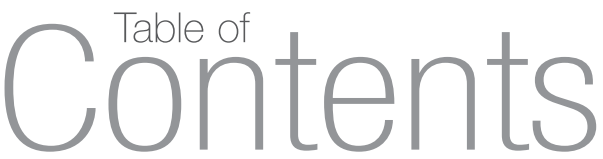

\section{From the Editor}

305 Contesting Authoritarianism

Jeffrey C. Isaac

\section{Articles}

313 Autocratic Breakdown and Regime Transitions: A New Data Set

Barbara Geddes, Joseph Wright, and Erica Frantz

332 The Ballot and the Street: An Electoral Theory of Social Protest in Autocracies

Guillermo Trejo

353 Economic Origins of Democratic Breakdown? The Redistributive Model and the Postcolonial State

Dan Slater, Benjamin Smith, and Gautam Nair

375 The Law's Majestic Equality? The Distributive Impact of Judicializing Social and Economic Rights Daniel M. Brinks and Varun Gauri

\section{Reflections Symposium}

394 Explaining the Unexpected: Political Science and the Surprises of 1989 and 2011 Marc Morjé Howard and Meir R. Walters

409 Response to Howard and Walters Eva Bellin

413 Response to Howard and Walters Ellen Lust

415 Response to Howard and Walters Marc Lynch

Cover Art: January 12, 2014 (Kiev) - Protesters shout slogans during mass rally of the pro-Western Ukrainian opposition on Independence Square. Some 50,000 Ukrainians gathered in the heart of Kiev amidst swelling anger over the bloody beating of prominent former minister turned opposition leader Yuriy Lutsenko. Photo credit: SERGEI SUPINSKY/AFP/Getty Images. 
417 Response to Eva Bellin, Ellen Lust, and Marc Lynch Marc Morjé Howard and Meir R. Walters

\section{Reflection}

420 The Most Important Topic Political Scientists Are Not Studying: Adapting to Climate Change Debra Javeline

\section{Review Essays}

435 Democratic Politics in Times of Austerity: The Limits of Forced Reform in Greece Harris Mylonas

444 Islamism and Authoritarianism: Works Published on the Cusp of the Arab Uprisings Michaelle Browers

449 Choosing and Caring: Markets and Their Limits Jeff Spinner-Halev

455 The Great Disconnect: Occupy and Political Science Sanford F. Schram

\section{Review Symposium}

461 The Impossible State

A Discussion of Wael Hallaq's Islam, Politics, and Modernity's Moral Predicament

Iza Hussin

Nathan J. Brown

Neguin Yavari

\section{Critical Dialogue}

468 Reviews and Responses

Sidney Tarrow

The Language of Contention: Revolutions

in Words, 1688-2012.

\section{W. Lance Bennett}

The Logic of Connective Action:

Digital Media and the Personalization

of Contentious Politics.

\section{Book Reviews}

\section{CONTESTATION}

474 Kevin Arceneaux and Martin Johnson, Changing Minds or Changing Channels? Partisan News in an Age of Choice. Review by Matthew Levendusky

475 David C. Barker and Christopher Jan Carman, Representing Red and Blue: How the Culture Wars Change the Way Citizens Speak and Politicians Listen.

Review by Joseph Bafumi

476 Patrick Chabal, The End of Conceit: Western Rationality after Postcolonialism.

Review by George Ciccariello-Maher 
477 Robert S. Erikson and Christopher Wlezien, The Timeline of Presidential Elections: How Campaigns Do (and Do Not) Matter.

Review by Lynn Vavreck

479 Alin Fumurescu, Compromise: A Political and Philosophical History. Review by Ryan Patrick Hanley

480 Shannon Gleeson, Conflicting Commitments: The Politics of Enforcing Immigrant Worker Rights in San Jose and Houston. Review by Margaret Gray

Matthew Levendusky, How Partisan Media Polarize America. Review by Martin Johnson

483 Andrew J. Polsky, Elusive Victory: The American Presidency at War. Review by Brien Hallett

\section{AMERICAN POLITICS}

484 E. Scott Adler and John D. Wilkinson, Congress and the Politics of Problem Solving. Review by Adam Sheingate

485 John H. Aldrich and Kathleen M. McGraw, Improving Public Opinion Surveys: Interdisciplinary Innovation and the American National Election Studies. Review by Patrick R. Miller

Daniel Béland and Alex Waddan, The Politics of Policy Change: Welfare, Medicare and Social Security Reform in the United States. Review by Molly C. Michelmore

Cary Coglianese, Regulatory Breakdown: The Crisis of Confidence in U.S. Regulation. Review by Jeff Worsham

490 Richard F. Fenno, The Challenge of Congressional Representation. Review by Andrew J. Taylor

491 Andra Gillespie, The New Black Politician: Cory Booker, Newark and Post-Racial America. Review by Robert C. Smith

492 Daniel Martinez HoSang, Oneka LaBennett, and Laura Pulido, Racial Formation in the Twenty-First Century. Review by Jack Turner

494 Jeffrey A. Jenkins and Eric M. Patashnik, Living Legislation: Durability, Change, and the Politics of American Lawmaking. Review by Jesse H. Rhodes

495 Nathaniel J. Klemp, The Morality of Spin: Virtue and Vice in Political Rhetoric and the Christian Right. Review by Roderick P. Hart

496 Nolan McCarthy, Keith T. Poole, and Howard Rosenthal, Political Bubbles: Financial Crises and the Failure of American Democracy.

Review by Bryan D. Jones

499 Emily Zackin, Looking for Rights in All the Wrong Places: Why State Constitutions Contain America's Positive Rights.

Review by John Dinan

\section{COMPARATIVE POLITICS}

501 Merike Blofield, The Great Gap: Inequality and the Politics of Redistribution in Latin America.

Evelyn Huber and John D. Stephens, Democracy and the Left: Social Policy and Inequality in Latin America.

Stephen B. Kaplan, Globalization and Austerity Politics in Latin America. Review by Benjamin Goldfrank

Martin K. Dimitrov, Why Communism Did Not Collapse: Understanding Authoritarian Regime Resilience in Asia and Europe.

Review by Barbara Junisbai

Gabriel Goodliffe, The Resurgence of the Radical Right in France: From Boulangisme to the Front National. Review by Antonis A. Ellinas

506 Steven Heydemann and Reinoud Leenders, Middle East Authoritarianisms: Governance, Contestation and Regime Resilience in Syria and Iran.

Paul Aarts and Francesco Cavatorta, Civil Society in Syria and Iran: Activism in Authoritarian Contexts. Review by Jubin M. Goodarzi

508 Maiah Jaskoski, Military Politics and Democracy in the Andes. Review by Lindsay P. Cohn

509 Arie M. Kacowicz, Globalization and the Distribution of Wealth: The Latin American Experience, $1982-2008$. Review by Gabriel Ondetti 
Doug McAdam and Hilary Boudet, Putting Social Movements in Their Place: Explaining Opposition to Energy Projects in the United States, 2000-2005.

Review by Daniel P. Aldrich

512 Harris Mylonas, The Politics of Nation-Building: Making Co-Nationals, Refugees, and Minorities. Review by Dmitry Gorenburg

513 Andreas Tsolakis, The Reform of the Bolivian State: Domestic Politics in the Context of Globalization. Review by Jean-Paul Faguet

\section{POLITICAL THEORY}

515 Myron J. Aronoff and Jan Kubik, Anthropology and Political Science: A Convergent Approach. Review by John Borneman

517 Albena Azmanova, The Scandal of Reason. A Critical Theory of Political Judgment. Review by Maeve Cooke

519 William E. Connolly, A World of Becoming.

William E. Connolly, The Fragility of Things: Self-Organizing Processes, Neoliberal Fantasies, and Democratic Activism. Review by Bradley J. Macdonald

Joshua Derman, Max Weber in Politics and Social Thought: From Charisma to Canonization. Review by Dana Villa

Frank Fischer and Herbert Gottweis, The Argumentative Turn Revisited: Public Policy as Communicative Practice. Review by Hélène Landemore

Robert F. Gorman, Toward the Common Good: A Catholic Critique of the Discipline of Political Science. Review by Daniel J. Mahoney

Joshua Mitchell, Tocqueville in Arabia: Dilemmas in a Democratic Age. Review by Sheldon Gellar

Marc Mulholland, Bourgeois Liberty and the Politics of Fear: From Absolutism to Neo-Conservatism. Review by Jeremy Jennings

528 Ella Myers, Worldly Ethics: Democratic Politics and Care for the World. Review by Sara Rushing

Emile Perreau-Saussine, Catholicism and Democracy: An Essay in the History of Political Thought. Review by Robert P. Hunt

531 Sharon A. Stanley, The French Enlightenment and the Emergence of Modern Cynicism. Review by Henry C. Clark

532 Immanuel Wallerstein, The Modern World-System IV: Centrist Liberalism Triumphant, 1789-1914. Review by Aurelian Craiutu

534 Jennifer Nedelsky, Law's Relations: A Relational Theory of Self, Autonomy, and Law. Review by Kristin Bumiller

\section{INTERNATIONAL RELATIONS}

536 Alex J. Bellamy and Paul D. Williams, Providing Peacekeepers: The Politics, Challenges, and Future of United Nations Peacekeeping Contributions.

Laura Zanotti, Governing Disorder: UN Peace Operations, International Security, and Democratization in the Post-Cold War Era. Review by Paul F. Diehl

Bear F. Braumoeller, The Great Powers and the International System: Systemic Theory in Empirical Perspective. Review by John Agnew

539 Kent E. Calder, The New Continentalism: Energy and Twenty-First-Century Eurasian Geopolitics. Review by Derek McDougall

541 Stuart Croft, Securitizing Islam: Identity and the Search for Security. Review by Paul Roe

542 Nil Disco and Eda Kranakis, Cosmopolitan Commons: Sharing Resources and Risks across Borders. Review by Debra Javeline

543 Rosemary Foot and Andrew Walter, China, the United States, and Global Order.

Rosemary Foot, China Across the Divide: The Domestic and Global in Politics and Society. Review by Kai He

545 David C. Kang, East Asia Before the West: Five Centuries of Trade and Tribute.

Zheng Wang, Never Forget National Humiliation: Historical Memory in Chinese Politics and Foreign Relations. Review by Jack A. Goldstone 
548 Darius Ornston, When Small States Make Big Leaps: Institutional Innovation and High-Tech Competition in Western Europe.

Review by Jeffrey A. Hart

549 Brian C. Rathbun, Trust in International Cooperation: International Security Institutions, Domestic Politics, and American Multilateralism.

Review by Aaron M. Hoffman

551 Daniel Finke, Reforming the European Union: Realizing the Impossible.

Jürgen Habermas, The Crisis of the European Union: A Response.

Review by Richard Bellamy

552 Scott Fitzsimmons, Mercenaries in Asymmetric Conflicts.

Review by Lee Seymour

554 Review Index 


\section{Philosophy of Perspectives on Politics}

Perspectives seeks to nurture a political science public sphere, publicizing important scholarly topics, ideas, and innovations, linking scholarly authors and readers, and promoting broad reflexive discussion among political scientists about the work that we do and why this work matters.

A full-length copy of the journal's editorial philosophy appears in Perspectives on Politics 8(1): 7-10 and also on the web at http://www.apsanet.org/content_44375.cfm.

\section{Submission and Review}

For submission guidelines, please see http://www.apsanet.org/content_44360.cfm.

Our editorial team discusses all submissions. Those that seem promising are evaluated by several external reviewers - with full confidentiality on both sides - and then accepted, returned for further revisions, or declined with suggestions of more appropriate venues for publication.

\section{CONTACT INFO}

Perspectives on Politics

Department of Political Science

1100 E. 7th St

Woodburn Hall 210G

Indiana University

Bloomington, IN 47405

Perspectives: perspectives@apsanet.org

Book Reviews: reviews@indiana.edu

\section{Perspectives on Politics}

\author{
Editor \\ Jeffrey C. Isaac, Indiana University, 2009- \\ Managing Editor \\ James Moskowitz \\ Assistants to the Editor \\ Laura C. Bucci \\ Adrian Florea \\ Brendon Westler \\ Rafael Khachaturian \\ Rachel Gears \\ Peter S. Giordano
}

Associate Editors

Edwina Barvosa, University of California, Santa Barbara

Richard Battistoni, Providence College

Michael Bernhard, University of Florida

Charli Carpenter, University of Massachusetts, Amherst

Daniel Drezner, Fletcher School, Tufts University

Henry Farrell, George Washington University

Page Fortna, Columbia University

Ange-Marie Hancock, University of Massachusetts, Amherst

Marc Morjé Howard, Georgetown University

Mala Htun, University of New Mexico

Bryan Jones, University of Texas, Austin

Stathis Kalyvas, Yale University

Mary Katzenstein, Cornell University

Mark Lynch, George Washington University

Samantha Majic, John Jay College, CUNY

Elizabeth S. Markovits, Mount Holyoke

Melissa Nobles, MIT

Timothy Kaufman-Osborn, Whitman College

Paul Pierson, University of California, Berkeley

Andrew Sabl, University of California, Los Angeles

James Scott, Yale University

Joe Soss, University of Minnesota

Paul Staniland, University of Chicago

Dara Strolovitch, University of Minnesota

Lisa Wedeen, University of Chicago
Association Office Address and Membership Information: American Political Science Association individual membership dues are as follow: Regular members with income $\$ 200,000$ + $\$ 320 ; \$ 135,000-\$ 199,999, \$ 271 ; \$ 100,000-\$ 134,000$ $\$ 241 ;$ \$80,000-\$99,999, \$207; \$60,000-\$79,999, \$186 $\$ 50,000-\$ 59,999, \$ 170 ; \$ 40,000-\$ 49,999$, $\$ 145$; less than $\$ 40,000$, $\$ 98$; Student members, $\$ 45$; Retired members with income $\$ 25,000+$, \$66; Retired members with income less than $\$ 25,000, \$ 40$; Life members: $\$ 3,000$; Unemployed members: \$45; Associate member with one journal selection, \$62. The amount of the dues allocated for a subscription is $\$ 6.75$ for an individual membership. Changes of address for members should be completed online or mailed to the APSA membership office at: APSA, 1527 New Hampshire Avenue, N.W., Washington, DC 20036.

Subscription, Publishing, and Advertising Office Address: Cambridge University Press, 32 Avenue of the Americas, New York, NY 10013; and (for correspondents outside the United States, Canada, and Mexico) Cambridge University Press, The Edinburgh Building, Shaftesbury Road, Cambridge CB2 8RU, England

Subscription Information: Perspectives on Politics (ISSN 1537 5927) is published quarterly, in March, June, September, and December, by Cambridge University Press for the American Political Science Association. Annual institutional electronic-only subscription rate (2014) is US\$1119 in the United States, Canada, and Mexico; £625 elsewhere. Annual institutional print-andelectronic subscription rate (2014) is US\$1297 in the United States, Canada, and Mexico; $₹ 716$ elsewhere. Perspectives on Politics is sold only as part of a joint subscription with the American Political Science Review and PS: Political Science \& Politics. Single part rate (2014) is US\$138 in the United States, Canada, and Mexico; £69 elsewhere. Periodicals postage rate paid at New York, NY, and additional mailing offices. Postmaster: Send address changes to Perspectives on Politics, Cambridge University Press, 100 Brook Hill Drive, West Nyack, NY 10994-2133, U.S.A.

(c) American Political Science Association 2014

All rights reserved. No part of this publication may be reproduced, in any form or by any means, electronic, photocopying, or otherwise, without permission in writing from Cambridge University Press. Policies, request forms, and contacts are available from: http://www.cambridge.org/rights/permissions/ permission.htm

Permission to copy (for users in the U.S.A) is available from the Copyright Clearance Center, http://www.copyright.com email: info@copyright.com.

Individual Copies: Single copies of Perspectives on Politics may be purchased for $\$ 25.00$

Microfilm Editions: Microfilm editions of Perspectives on Politics are available from ProQuest Information and Learning, Ann Arbor, Ml 48106. (800) 521-0600.

Advertising: Perspectives on Politics has a circulation of 16,000 . For information on advertising rates and mechanical requirements, contact Advertising Coordinator, Cambridge University Press, 32 Avenue of the Americas, New York, NY 10013. (212) 337-5000.

Composition: TNQ Books and Journals Pvt. Ltd., Chennai, India. Printing and Distribution: The Sheridan Press, Hanover, PA. 


\section{About APSA}

Founded in 1903, the American Political Science Association is the leading professional organization for the study of political science and serves more than 15,0oo members in over 80 countries. With a range of programs and services for individuals, departments, and institutions, APSA brings together political scientists from all fields of inquiry, regions, and occupational endeavors within and outside academe in order to expand awareness and understanding of politics.

The direct advancement of knowledge is at the core of APSA activities. We promote scholarly communication in political science through a variety of initiatives including publishing three distinguished journals: American Political Science Review, Perspectives on Politics, and PS: Political Science and Politics.

\section{Officers}

\section{PRESIDENT}

John H. Aldrich

Duke University

\section{PRESIDENT-ELECT}

Rodney E. Hero

University of California, Berkeley

\section{VICE-PRESIDENTS}

Philip Keefer

The World Bank

\section{J. Donald Moon \\ Wesleyan University}

Melissa Nobles

Massachusetts Institute of Technology

\section{TREASURER}

Kathleen Thelen

Massachusetts Institute of Technology

\section{SECRETARY}

K.C. Morrison

Mississippi State University

\section{PROGRAM CO-CHAIRS}

Simon Jackman

Stanford University

Melanie Manion

University of Wisconsin, Madison

\section{EDITOR-IN-CHIEF, APSR}

John Ishiyama

University of North Texas

\section{EDITOR-IN-CHIEF, PERSPECTIVES \\ Jeffrey C. Isaac \\ Indiana University}

\section{EXECUTIVE DIRECTOR}

Steven Rathgeb Smith

American Political Science Association

\section{Council}

\section{2-2014}

Gretchen G. Casper

Pennsylvania State University

Brian F. Crisp

Washington University, St. Louis

Page Fortna

Columbia University

Juan Carlos Huerta

Texas A\&M University-Corpus Christi

Junko Kato

University of Tokyo

Joanne Miller

University of Minnesota

Todd C. Shaw

University of South Carolina

Kenneth D. Wald

University of Florida

2013-2015

Amrita Basu

Amherst College

Kenneth R. Benoit

London School of Economics

Christine Di Stefano

University of Washington

James N. Druckman

Northwestern University

Hank C. Jenkins-Smith

University of Oklahoma

David C. Kang

Universtiy of Southern California

John M. Sides

George Washington University

Evelyn M. Simien

University of Connecticut

\section{Former APSA Presidents}

Frank J. Goodnow

Albert Shaw

Frederick N. Judson

James Bryce

A. Lawrence Lowell

Woodrow Wilson

Simeon E. Baldwin

Albert Bushnell Hart

W. W. Willoughby

John Bassett Moore

Ernst Freund

Jesse Macy

Munroe Smith

Henry Jones Ford

Paul S. Reinsch

Leo $S$. Rowe

William A. Dunning

Harry A. Garfield

James W. Garner

Charles E. Merriam

Charles A. Beard

William Bennett Munro

Jesse S. Reeves

John A. Fairlie

Benjamin F. Shambaugh

Edward S. Corwin

William F. Willoughby

Isidor Loeb

Walter Shepard

Francis W. Coker

Arthur N. Holcombe

Thomas Reed Powell

Clarence A. Dykstra

Charles Grove Haines

Robert C. Brooks

Frederic A. Ogg

William Anderson

Robert E. Cushman

Leonard D. White

John Gaus

Walter F. Dodd

Arthur W. MacMahon

Henry R. Spencer

Quincy Wright

James K. Pollock

Peter H. Odegard

Luther Gulick

Pendleton Herring

Ralph J. Bunche

Charles McKinley

Harold D. Lasswell

E. E. Schattschneider

V. O. Key Jr.

R. Taylor Cole
Carl B. Swisher Emmette S. Redford Charles S. Hyneman Carl J. Friedrich

C. Herman Pritchett David B. Truman

Gabriel A. Almond Robert A. Dahl

Merle Fainsod

David Easton

Karl W. Deutsch

Robert E. Lane

Heinz Eulau

Robert E. Ward

Avery Leiserson

Austin Ranney

James MacGregor Burns

Samuel H. Beer

John C. Wahlke

Leon D. Epstein

Warren E. Miller

Charles E. Lindblom

Seymour Martin Lipset

William H. Riker

Philip E. Converse

Richard F. Fenno

Aaron B. Wildavsky

Samuel P. Huntington

Kenneth N. Waltz

Lucian W. Pye

Judith N. Shklar

Theodore J. Lowi

James Q. Wilson

Lucius J. Barker

Charles O. Jones

Sidney Verba

Arend Lijphart

Elinor Ostrom

M. Kent Jennings

Matthew Holden Jr.

Robert O. Keohane

Robert Jervis

Robert D. Putnam

Theda Skocpol

Susanne Hoeber Rudolph

Margaret Levi

Ira Katznelson

Robert Axelrod

Dianne M. Pinderhughes

Peter Katzenstein

Henry E. Brady

Carole Pateman

G. Bingham Powell, Jr.

Jane Mansbridge 


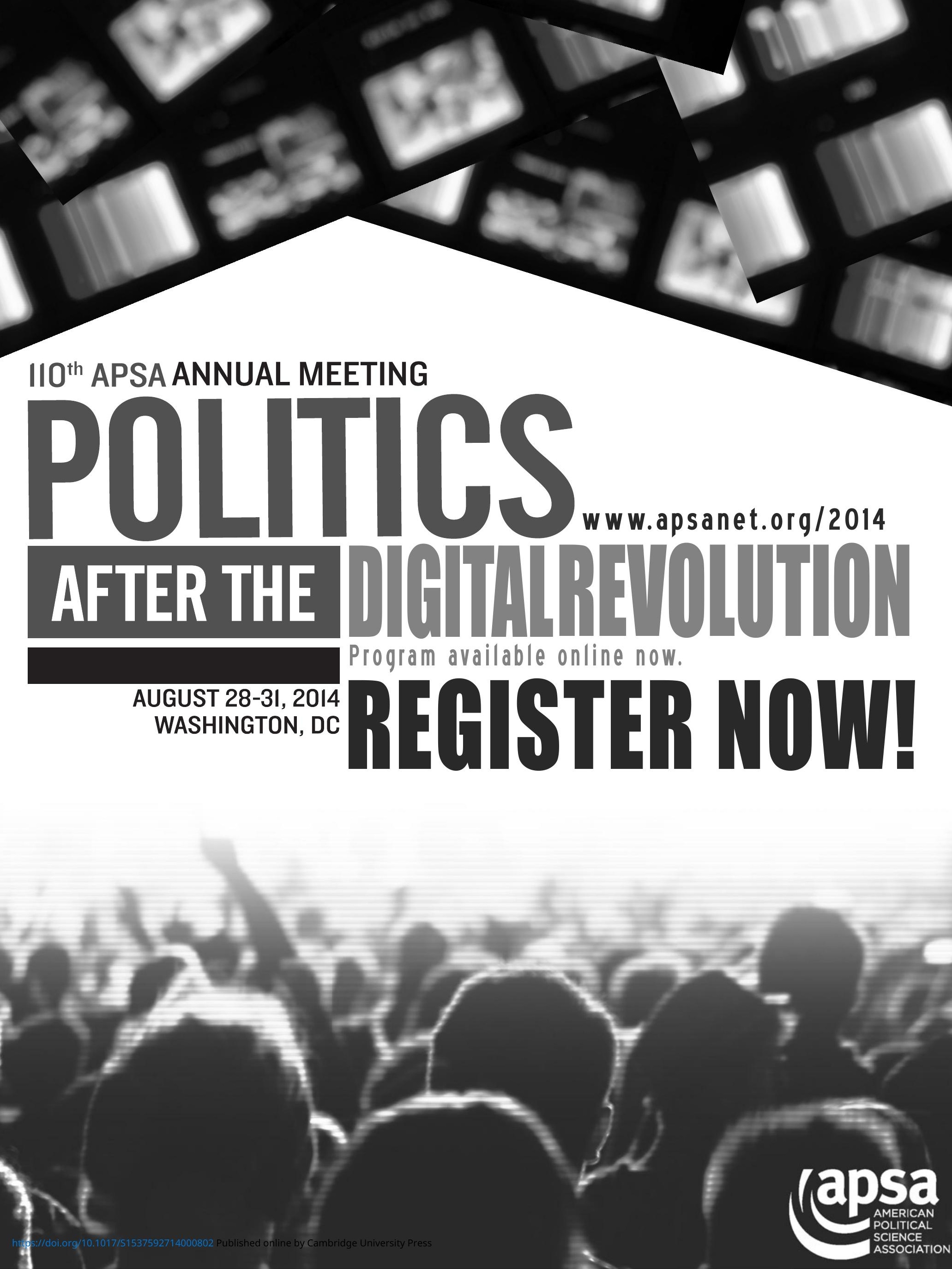

